Original paper

\title{
GYNE AND DRONE PRODUCTION IN BOMBUS ATRATUS
}

\section{(HYMENOPTERA: APIDAE)}

\author{
Sandy C. Padilla ${ }^{1 *}$ \\ José R. Cure ${ }^{1,3}$ \\ Diego A. Riaño ${ }^{1}$ \\ Andrew P. Gutierrez 2,3 \\ Daniel Rodriguez ${ }^{1,3}$ \\ Eddy Romero ${ }^{1}$
}

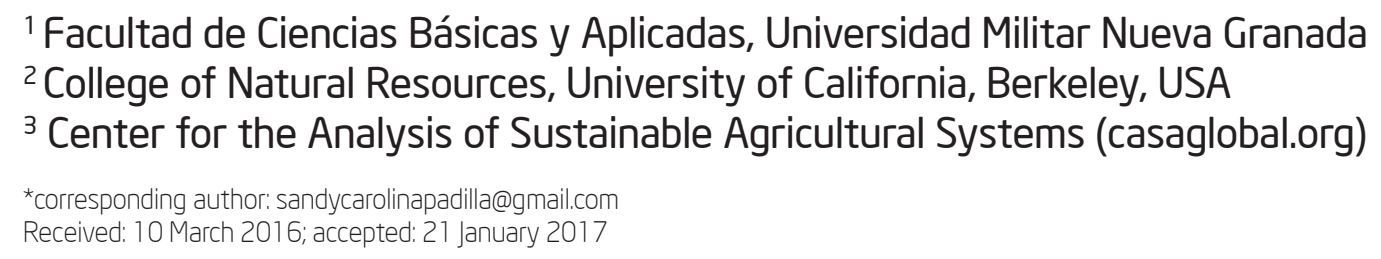

A bstract

For over a decade, our research group has studied the biology of the native bumblebee, Bombus atratus, to investigate the feasibility of using it to pollinate crops such as tomato, strawberry, blackberry and peppers. Traditionally, captive breeding has depended on the use of captured wild queens to initiate the colonies. The goal of the current work is to investigate conditions required to produce new queens and drones in captivity. In this study, 31 colonies were evaluated under either greenhouse or open field conditions over a 15 month period. A total of 1492 drones (D) and 737 gynes (G, i.e., virgin queens) were produced by all colonies, with 16 colonies producing both drones and gynes (D\&G), 11 producing only drones (D) and 4 producing neither. Some of the D\&G colonies had more than one sexual phase, but no colonies produced exclusively gynes. More drones and fewer gynes were produced per colony under greenhouse conditions with the highest number of drones produced by D\&G colonies. The numbers of immature stages per cell declined in colonies as increasingly more resources were allocated to the production of gynes and the maintenance of increased nest temperature.

Keywords: bee breeding, bumbleebees, sex allocation, sexual forms

\section{INTRODUCTION}

Non-parasitic bumblebees in the genus Bombus are morphologically a very homogeneous group of social bees. There are 239 species worldwide, of which 42 are Neotropical with 12 occurring in Colombia (Williams, 1998; Abrahamovich \& Díaz, 2002).

Field studies on rearing the native bumblebee in Colombia began in 1998, with B. atratus recognized early on as a very promising pollinator species because it can develop strong colonies in artificial chambers, thrives in grasslands and has a broad geographical distribution (Cruz, Almanza \& Cure, 2007).

Our study describes the growth and development of $B$. atratus colonies from the time the queen was captured in the field through the sexual phase culminating in the production of gynes $(G)$ and drones $(D)$. The goal was to provide basic data to enable successful production of gynes and drones for commercial production.

\section{Biology of B. atratus}

In Colombia, $B$. atratus is common in the Eastern range of the Andes, being most abundant from 1800 to 2800 meters above sea level (masl) (Liévano, Ospina \& Nates, 1994; Abrahamovich \& Díaz, 2002; Cruz, Almanza \& Cure, 2007). In Facatativá, Bogotá's Savanah, Colombia, the sexual forms (gynes and drones) appear from November to January and from June to August during periods of low rainfall (González, Mejía \& Rasmussen, 2004). In contrast to other Bombus 
species in northern latitudes, colonies of $B$. atratus survive from 1 to 10 years and may produce two cycles of sexual forms per year (Zucchi, 1973).

A typical $B$. atratus successful colony has the following four phases of development (modified from Duchateau \& Velthuis, 1988): 1) the initiation phase includes the solitary period of colony formation by the founder queen to the emergence of all the workers from the first cell; 2) the linear phase of colony is characterized by a linear increase in the cumulative number of cells per day; 3 ) the sexual phase starts when the first gyne/drone egg are laid by the founder queen and lasts to the emergence of all gynes, and 4) the post-sexual phase is when colonies can be reactivated by a new queen or by a laying worker, or decay due to competition among the workers.

In nature, $B$. atratus builds nests in rodent burrows 4-5 cm below the soil surface. The colony expands vertically as new cells are built upon older ones. Cell volume average $5.2 \pm 0.1$ $\mathrm{mm}^{3}$ and 4 to 15 eggs are laid horizontally in each cell (González, Mejía \& Rasmussen, 2004). $A$ unique feature of bumblebees such as $B$. atratus is that as the larvae mature, they are progressively separated into individual cells (Sladen, 1912; Michener, 1974, 2007). Larvae enclose themselves after 6 - 9 days and continue to develop in cells that are increased in size to accommodate larval growth (Fig. 1). Furthermore, $B$. atratus is a pocket maker species that builds wax pockets linked to the cells of developing larvae and are provisioned with pollen as food for the larvae (Sladen, 1912). During the establishment phase of the colony, the pockets are built and provisioned by the queen, and later by workers. Depending on the number of eggs in the cell, one or two pockets are built per cell (González, Mejía \& Rasmussen, 2004).

The mean developmental time from oviposition to adult worker emergence is $29 \pm 5$ days, but this varies with temperature and food availability. The average developmental time of larvae is $13.9 \pm 4.4$ days, and $8.7 \pm 3.6$ days for pupae (Riaño et al., 2014). These times vary with nest temperature that may be regulated by the colony. In Facatativá, Cundinamarca, Colombia, González, Mejía \& Rasmussen (2004) reported a mean temperature of $27.2^{\circ} \mathrm{C}$ in $B$. atratus nest that was $11.5^{\circ} \mathrm{C}$ higher than ambient.

$B$. atratus has a medium length glossae that enables it in grasslands to forage on the commonly available red clover (Trifolium pratense) and to pollinate various horticulture crops. In Colombia, $B$. atratus has been evaluated as a pollinator of such crops as uchuva, Physalis peruviana (Camelo et al., 2004); strawberries, Fragaria x ananassa (Perez, 2014); tomatoes,

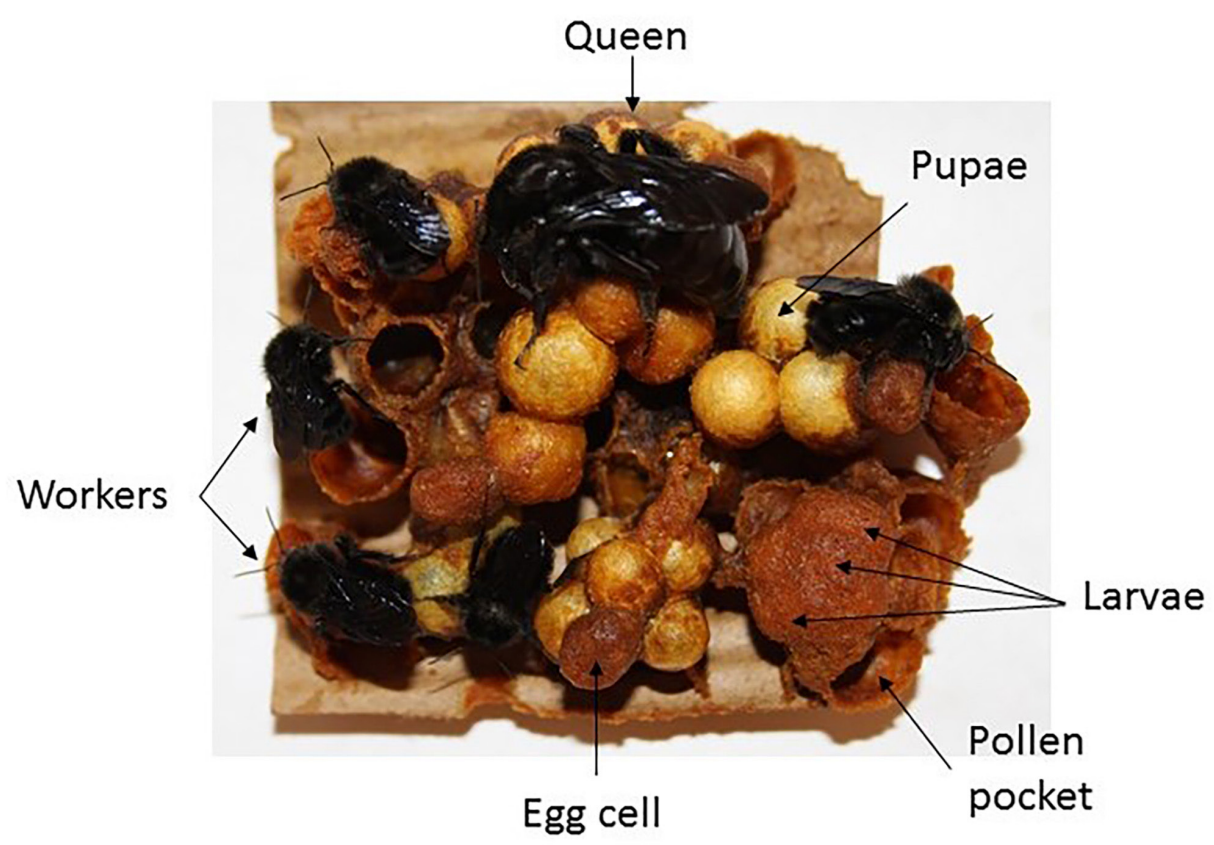

Fig.1 Colony structure of Bombus atratus 
Solanum lycopersicum (Aldana et al., 2007); lulo, Solanum quitoense (Almanza, 2007); blackberries, Rubus silvestris (Zuluaga, 2011); red clover, Trifolium pratense (Lobatón, Cure \& Almanza, 2012) and peppers, Capsicum annuum (Riaño et al., 2015).

\section{MATERIAL AND METHODS}

\section{Study Area}

The study was conducted during a 15 months period from April 2012 to July 2013 at the campus of the University of Nueva Granada located in the municipality of Cajicá (Cundinamarca, Colombia) at 2580 masl. The surrounding vegetation is mostly pastureland of the exotic tropical kikuyu grass (Pennisetum clandestinum) that is native to East Africa and interspersed with red clover. 21 colonies were placed in an open field where they were allowed to forage (Fig. 2, A and C), while another 10 colonies were housed in a $4000 \mathrm{~m}^{2}$ greenhouse (Fig. 2, B) where they could forage on Solanum quitoense, Brassica rapa, Raphanus sativus, Helianthus annuus, Dahlia imperialis, Phytolacca bogotensis and Borago officinalis provisioned for this purpose (Romero et al., 2013). These colonies also had access to the open field.

\section{Origin and maintenance of the bumble bee colonies}

All colonies were initiated using queens collected in the pastureland around the university campus. It was not possible to know the age of the queens with certainty as some had not yet started a colony and others had not yet produced their first batch of workers and were in the process of initiating a colony. Newly captured queens were placed individually in $15 \times 10 \times 10 \mathrm{~cm}$ initiation boxes in a laboratory breeding room held at $26 \pm 2^{\circ} \mathrm{C}$ and $60 \pm 5 \% \mathrm{RH}$ where they were fed commercially available pollen collected by from Apis mellifera hives and sucrose syrup (Pacateque et al., 2012). Each box was marked with where and when the queen was captured, as well as the dates of first oviposition and first worker emergence. When a colony had around five workers, it was moved to a larger $30 \times 20 \times 20 \mathrm{~cm}$ box where it was fed manually for 60 to 136 days. The differences in feeding time before moving a colony to whether the field or the greenhouse constitute a feeding time $x$ foraging treatment.

Thirty-one colonies were moved to the field in

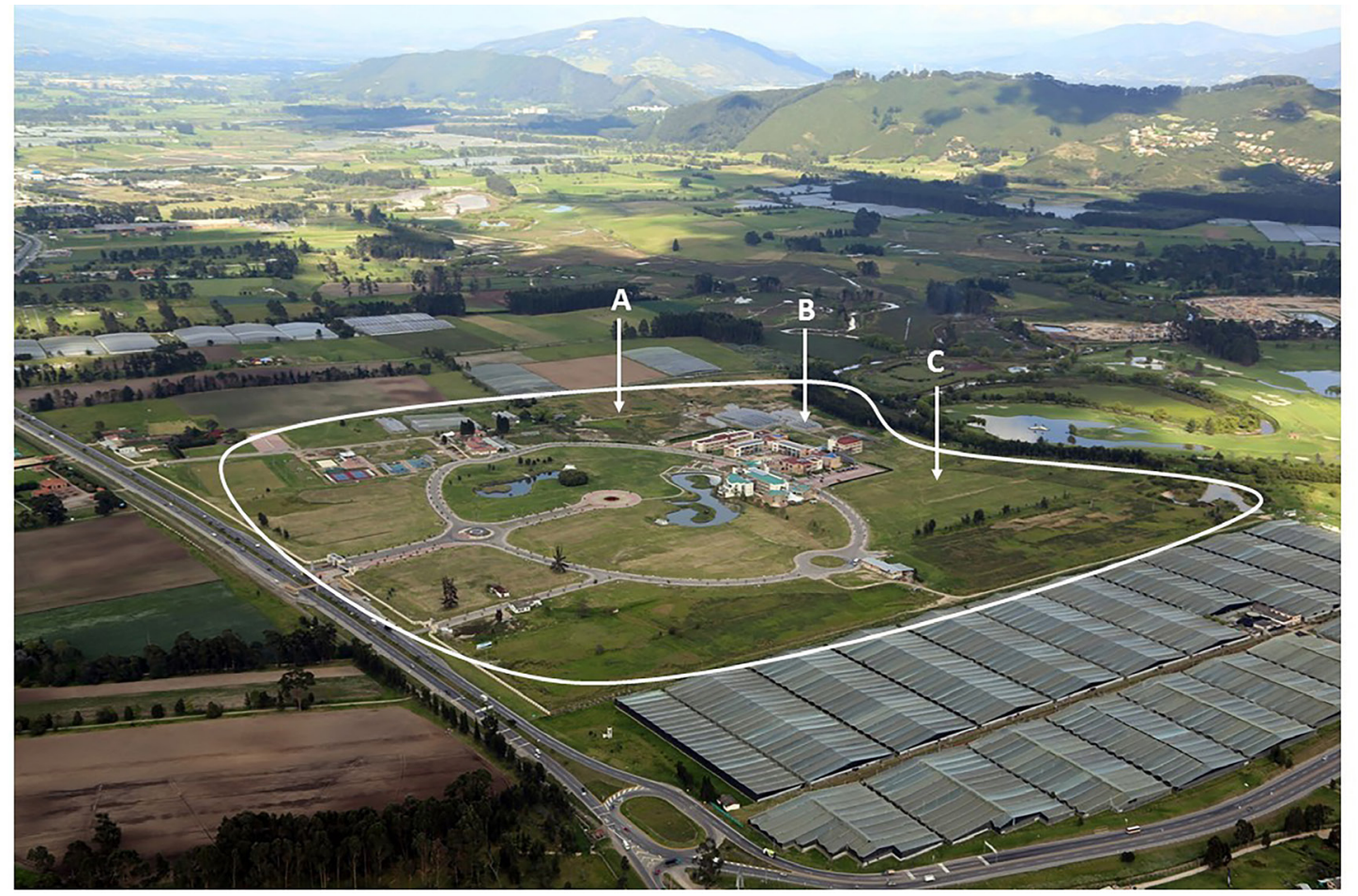

Fig. 2 Study areas at the Campus of the Nueva Granada University: 15 colonies were placed in open fields in zone $A$ and 6 in zone $C$, with 10 colonies maintained in a greenhouse $(B)$. 
$42 \times 26 \times 30 \mathrm{~cm}$ polystyrene boxes with a PVC tube that allowed the bumblebees access to the field. Nine colonies were moved to the field in September-October and twelve in DecemberFebruary. The ten remaining colonies were placed in the greenhouse during DecemberFebruary in $42 \times 26 \times 30 \mathrm{~cm}$ polystyrene boxes each having 2 PVC tubes that allowed workers to forage either in the greenhouse or in the field. The temperatures inside the boxes of some colonies in the field were monitored using a HOBO ${ }^{\circledR}$ data logger U12-012 (Onset Computer Corporation, 2013).

\section{Sampling data and statistical analysis Sampling}

Photographic records of all colonies were used to determine the timing of the important phenological events in each colony using the number of days after the capture of the founding queen (DAC) as a reference. Counts of immature stages, the dates of queen death and the emergence of the first gynes and drones were assessed twice a week, and the cumulative number of cells, larvae and pupae (workers + drones and gynes) and adults were plotted chronologically. Ignoring the stage subscript, the weekly data were used to estimate the changes in the numbers in each stage $\left(\Delta S_{t}\right)$ over time (eqn. 1a), with the cumulative numbers $\left(S_{t}\right)$ at time $t$ computed using eqn. 1b (cf. Gutierrez et al., 1981).

$$
\begin{gathered}
\Delta S_{t}=\frac{\left(N_{t}+N_{t-\Delta t}\right)}{2} * \Delta t / D E L \\
S_{t}=S_{t-\Delta t}+\Delta S_{t}
\end{gathered}
$$

$N_{t}$ is the number of immatures in the stage at time $t(\mathrm{DAC}), \mathrm{N}_{(t-\Delta t)}$ is the number at time $t-\Delta t$ and $D E L$ is the development time of each stage in days: egg $=7$, larvae $=15$, pupae $=10$, gyne larvae $=17$, gyne pupae $=16$.

Gynes and drones in each colony were counted and removed twice weekly. The colonies were classified by location (field or greenhouse), and class as gyne and drone producing colonies $(D \& G)$, drone producing colonies $(D)$ and colonies that produced only workers $(W)$.

\section{Statistical analyses}

Nested ANOVA was used to evaluate wing length, head width, weight and the number of drones as a function of colony location and class. Six variables were analyzed to determine their importance in the switching of the colonies from worker to gyne production: (1) days in captivity, (2) initial number of workers (w) produced during the period of captivity, (3) days to the emergence of the first worker, (4) days to emergence of the first drone, (5) longevity of the founder queen and (6) foraging location of the colonies. A Logistic Generalized Linear regression model (Equation 2) with backward elimination was used to determine the significance of the independent variables $\left(x_{1}, x_{2}, x_{3} \ldots\right.$ $\left.x_{\mathrm{n}}\right)$ in predicting the probability of producing $D \& G$ colonies $\left(P_{D \& G}(x)\right)$ where $a, b, c, d$... $h$ were fitted parameters (see; MacCullagh \& Nelder, 1989).

$$
P_{D \& G \text { colonies }}=\frac{e^{a+b x_{1}+c x_{2}+d x_{3}+\cdots \cdot h x_{n}}}{1+e^{a+b x_{1}+c x_{2}+d x_{3}+\cdots h x_{n}}}
$$

In addition, how the season (i.e., month) when the colonies were placed in the field affected the probability of gynes being produced and the number of gynes produced was analyzed using linear mixed models with Bayesian parameter estimation (Markov-Monte-Carlo chains with binomial or Poisson probability distributions; Hadfield, 2010).

\section{Resource allocation}

During colony development, more resources begin to be allocated to the rearing of gynes and less to the rearing of workers. To better describe this shift in resource allocation, we used as references the time of queen death $\left(t_{0}\right)$ and two additional reference times: 20 days before queen death $\left(t_{-20}\right)$ and 40 days before queen death $\left(t_{-4}\right)$. Using the data from the eight $D \& G$ and eleven $D$ colonies at times $t_{0,} t_{-20}$ the cumulative number of pupae (worker+drones) displaced +20 days $\left(Y_{T}\right.$, where $\left.\mathrm{T}=\mathrm{T}_{+20 \text { days }}\right)$ on the numbers of cumulative cells $\left(X_{T}\right.$, where $\mathrm{T}=$ $t_{0}$ or $\left.t_{-20}\right)$ were calculated. A covariance analysis using a linear mixed model for repeated meas- 

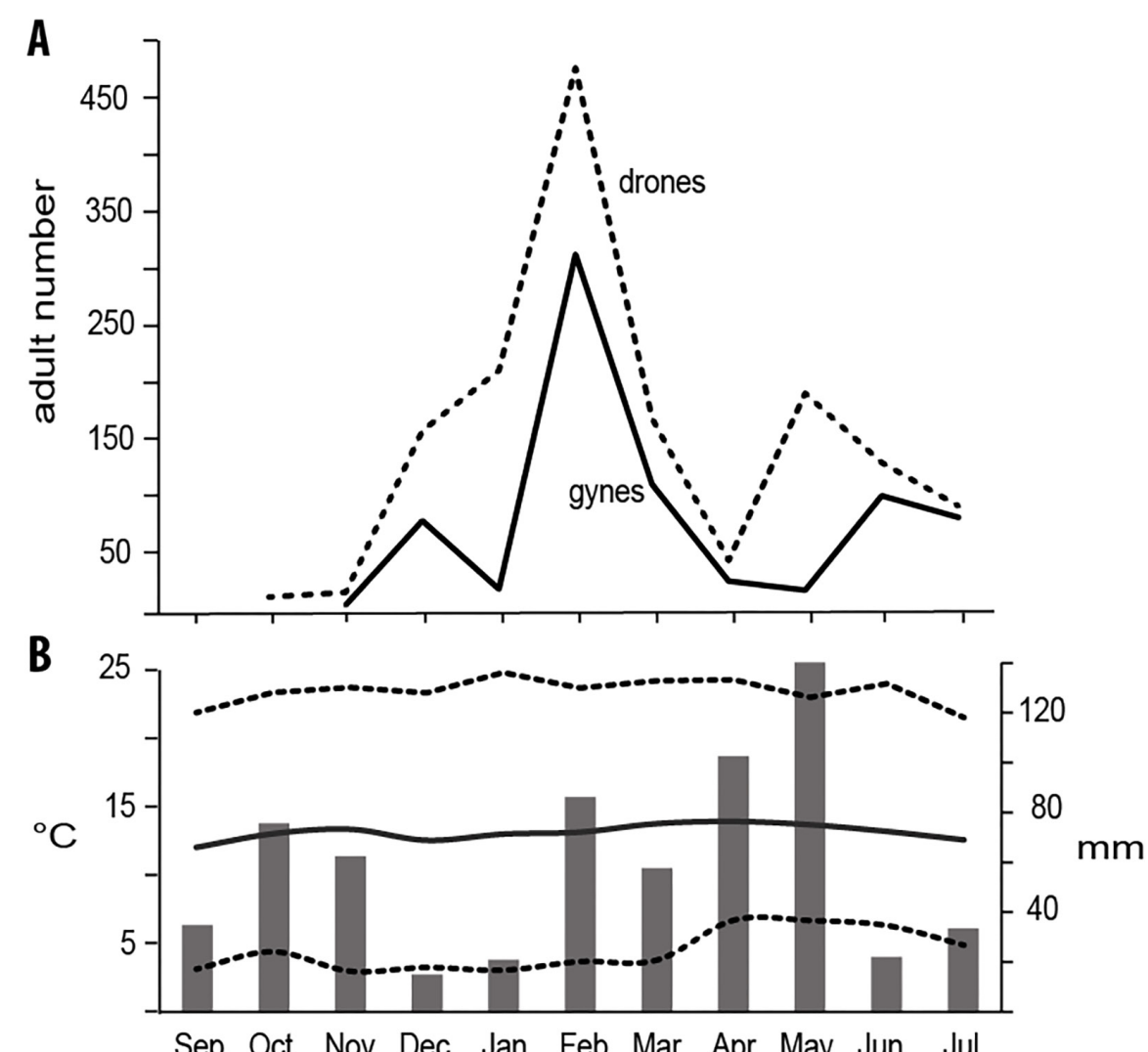

Fig.3 A: Total number of drones and gynes produced by all colonies between September, 2012 and July, 2013. B: Local weather during the period with bars representing mean rainfall, and lines represent temperatures: maximum, minimum and average.

urements was done to compare the curves at different moments from queen death (Everitt, 2005). A multiple regression analysis was used to assess the shift in resource allocation in the eight $D \& G$ colonies for $\mathrm{T}=\mathrm{t}_{0^{\prime}} \mathrm{t}_{-20}$ and $\mathrm{t}_{-40}$.

\section{Temperature variation inside the colonies}

ANOVA and Tukey tests were used to compare minimum, maximum and average temperatures inside the nest to ambient temperatures in six colonies with different initial sizes (two small, two medium and two large located in the open field) during the linear phase. The size of the colony was classified according to the number of workers when it was moved to the field. Temperatures in a $D \& G$ colony were compared to ambient during all phases of colony development.

\section{RESULTS}

\section{Sexual forms}

The total number of sexual forms produced by the 31 colonies during the fifteen months study period was 1492 drones and 737 gynes. Sixteen colonies produced drones and gynes $(D \& Q)$, eleven colonies produced only drones $(D)$ and four colonies produced only workers $(W)$. No colonies produced only gynes. Location did not affect the forming $D \& G$ colonies. One of the $D \& G$ colonies had a second cycle of drones and gynes, and another completed a third cycle, both of them located in the open field. Three $D$ colonies were reactivated by a new queen and produced drones and gynes.

Gynes and drones were produced continuously throughout the year but were more abundant in December-March and May-July (Fig. 3). More D\&G colonies were produced when the colonies were moved from captivity to the field in October ( $P<$ $0.01)$ and December $(P<0.05)$ (Fig. 4). Furthermore, more drones were produced per colony in the greenhouse than in the open field in both $D \& G$ and $D$ colonies ( $P<0.001)$, but no significant difference was observed in the number of gynes in the two locations ( $P>0.05)$ (Fig. 4). There was no difference in size of gynes in the open field and greenhouse treatments ( $P>0.05$ ). 
Drones

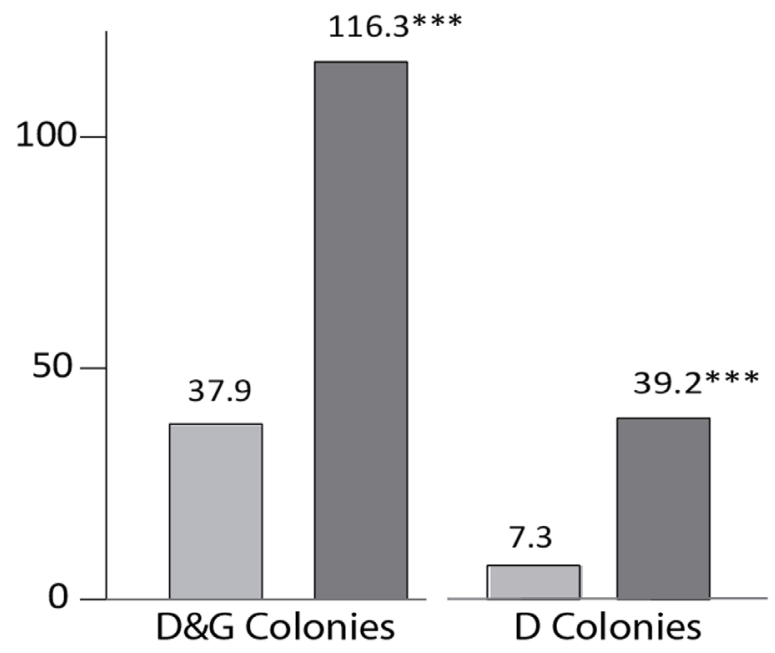

Gynes

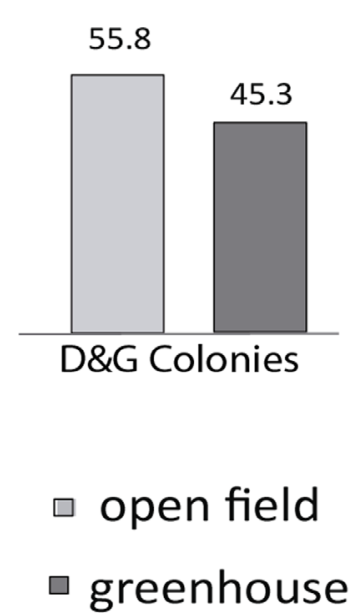

Fig. 4 Average number of drones and gynes produced per cycle per type of colony for D\&G and D colonies (all months included), where ${ }^{\star \star *}$ indicates significant differences $(P<0.001)$.

On the other hand, Drones were larger in $D \& G$ colonies than in $D$ colonies (Wing length $\mathrm{P}<0.05$; weight $\mathrm{P}<0.05)$ (Fig. 5).

Cells with larvae destined to become gynes have an operculated opening constructed for workers and used for direct feeding of the larvae (Fig. 6A). The operculated stage lasts for about 6.3 days and is followed by a prepupae-pupae stage of 16 days. The egg to adult cycle for gynes is about 40 days, approximately eight days longer

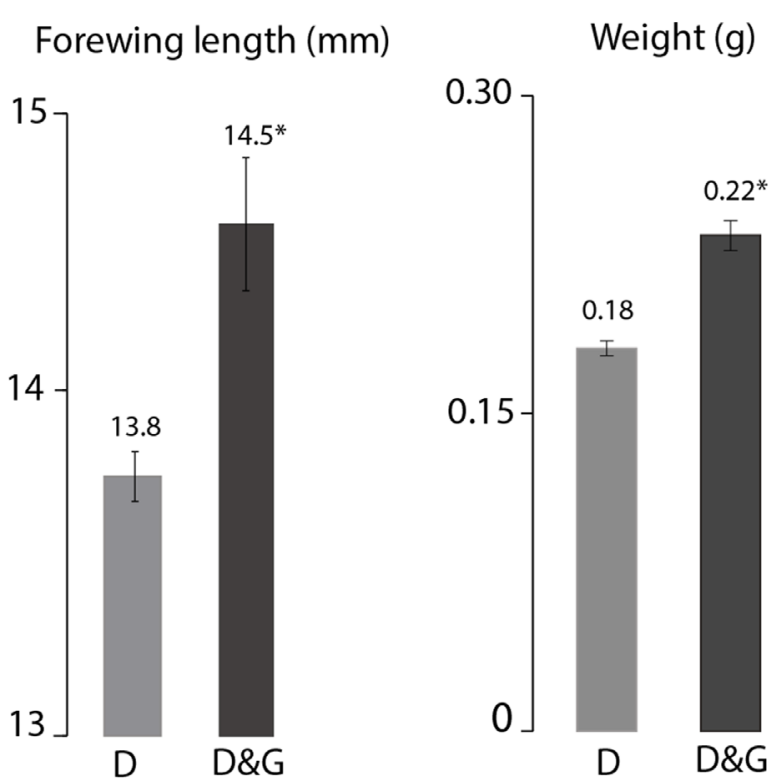

Fig. 5 Forewing length $(\mathrm{mm})$ and weight $(\mathrm{g})$ of drones produced in D\&G or D colonies.

*Significant differences $(P<0.05)$. than for workers. Pots filled with pollen were constructed at the same time as the first operculated cells appeared (Fig. 6 D).

Table 1 summarizes the average characteristics of the different classes of colonies. The longevity of founder queens was similar in $D \& G$ and $D$ colonies ( $P>0.05)$. However in all D\&G colonies, the founder queens died before the emergence of the first gyne indicating that developing immature gynes did not require the presence of the queen.

On average, the first drones emerged 12 days after the first operculated cells were formed and twelve days before the first adult gyne emerged.

Of the six factors evaluated for their effect on the production of $D \& G$ colonies, only days in captivity and number of workers produced in the colony during the captivity period ( $(w)$ were significant. Since both these factors are highly correlated, only the number of workers was used in the logistic regression; specifically, the probability of producing $D \& G$ colonies decreased as $w$ (Equation 3) increased (Fig. 7). Furthermore, colonies that were transferred early to the field produced more $D \& G$ colonies despite having fewer workers than colonies kept longer in the rearing chambers $(P<0.05)$. 
Table 1

Average values for the different colony classes: drones and gynes producing colonies (D\&G), or only drones producing colonies $(D)$.

\begin{tabular}{lcc}
\hline Variable & D\&G & D \\
\hline Number of colonies & 16 & 11 \\
Days in captivity & $99^{\star}$ & 118 \\
Number of workers & $118^{\star}$ & 177 \\
Number of drones $^{\mathrm{b}}$ & $78^{\star}$ & 23 \\
Number of gynes $^{\mathrm{b}}$ & 51 & - \\
Longevity of the founder queen $^{\mathrm{c}}$ & 147 & 146 \\
First adult drone $^{\mathrm{c}}$ & 160 & 172 \\
First operculated cell (gyne larvae) $^{\mathrm{c}}$ & 148 & - \\
First adult gyne $^{\mathrm{s}}$ & 172 & - \\
\hline
\end{tabular}

a total number of workers when a colony was transferred to free foraging,

${ }^{b}$ total produced in first cycle,

'days (from time of capture of the founder queen).

* Significant differences between the two classes of colonies $(P<0.05)$

$P_{D \& G \text { colonies }}=\frac{e^{(2.648692-0.01719 w)}}{1+e^{(2.648692-0.01719 w)}} ; p<0.05$

Resource allocation in $D \& G$ and $D$ colonies The analysis of covariance of cumulative pupae on cumulative cells for workers and drones for $D \& G$ and $D$ colonies generated a curve that started higher for $D \& G$ than for $D$ colonies, and indicated a greater colony capacity for provision food (i.e., higher colony vigor). The slopes of the curves at $t_{0}$ (i.e., the time of queen death) and $t_{-20}$ were significantly lower for $D \& G$ colonies than for $D$ colonies $(P<0.1)$. Furthermore, in $D \& G$ colonies the curve for time $t_{0}$ had a lower slope than the curve at $t_{-20}$ (Fig. 8A). This result indicated that the number of pupae produced per cell was lower for $D \& G$ colonies at this point in colony development showing that more resources were being allocated to the production of higher-energy-cost gynes than to workers.
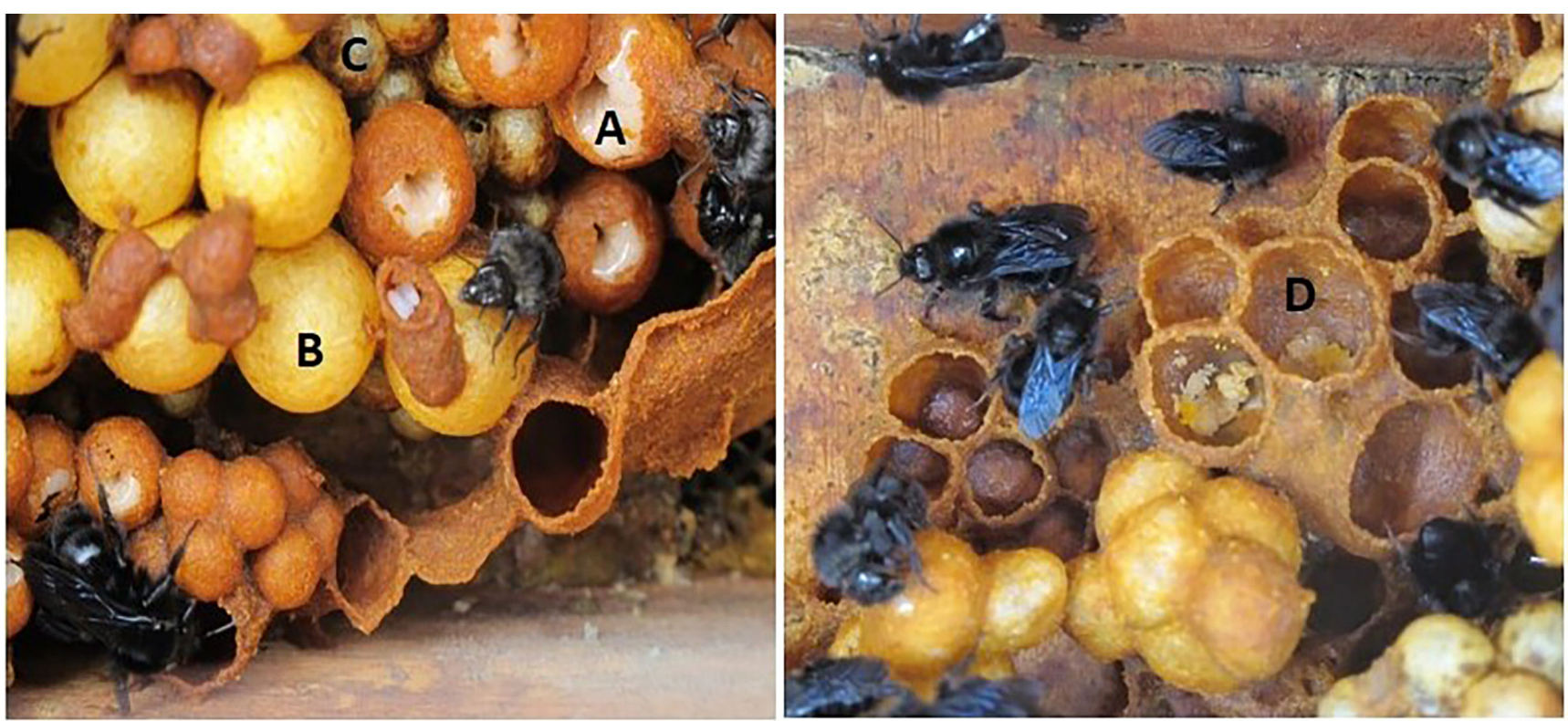

Fig. 6 Production of sexual forms in D\&G colonies. A: operculated cell (Gyne larvae); B: gyne pupae; C: worker or drone pupae; D: pollen storage cell. 


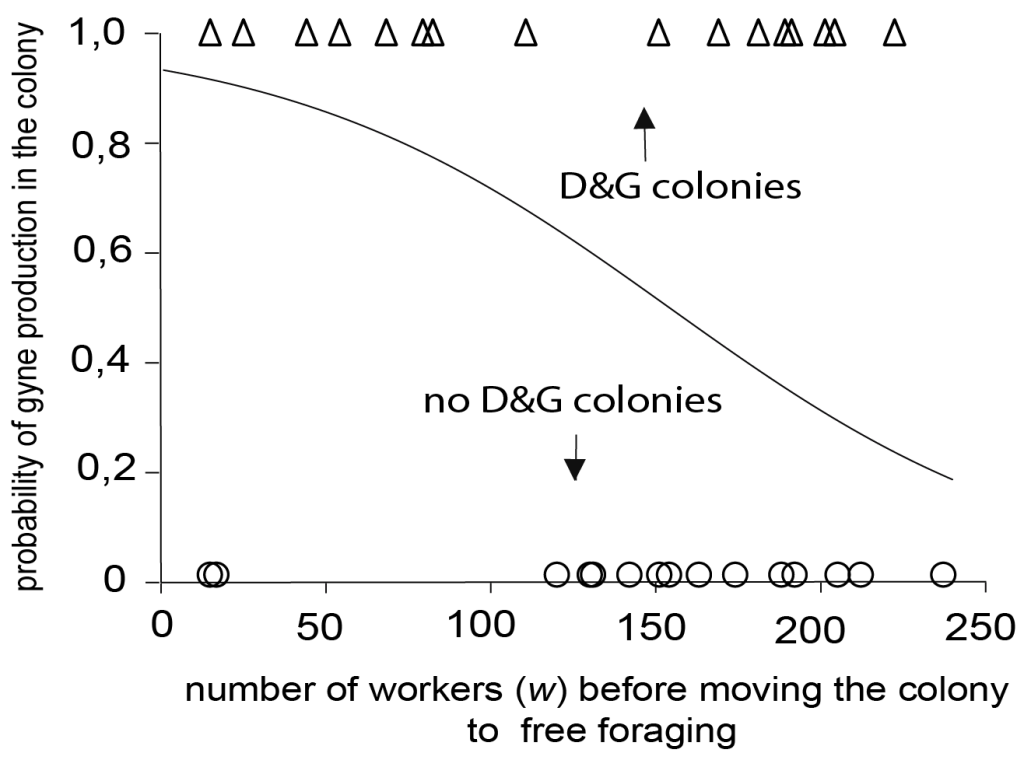

Fig. 7 Logistic model describing the probability of producing gynes at the end of the colony cycle as a function of the number of workers produced in captivity before the colonies were moved to field conditions.

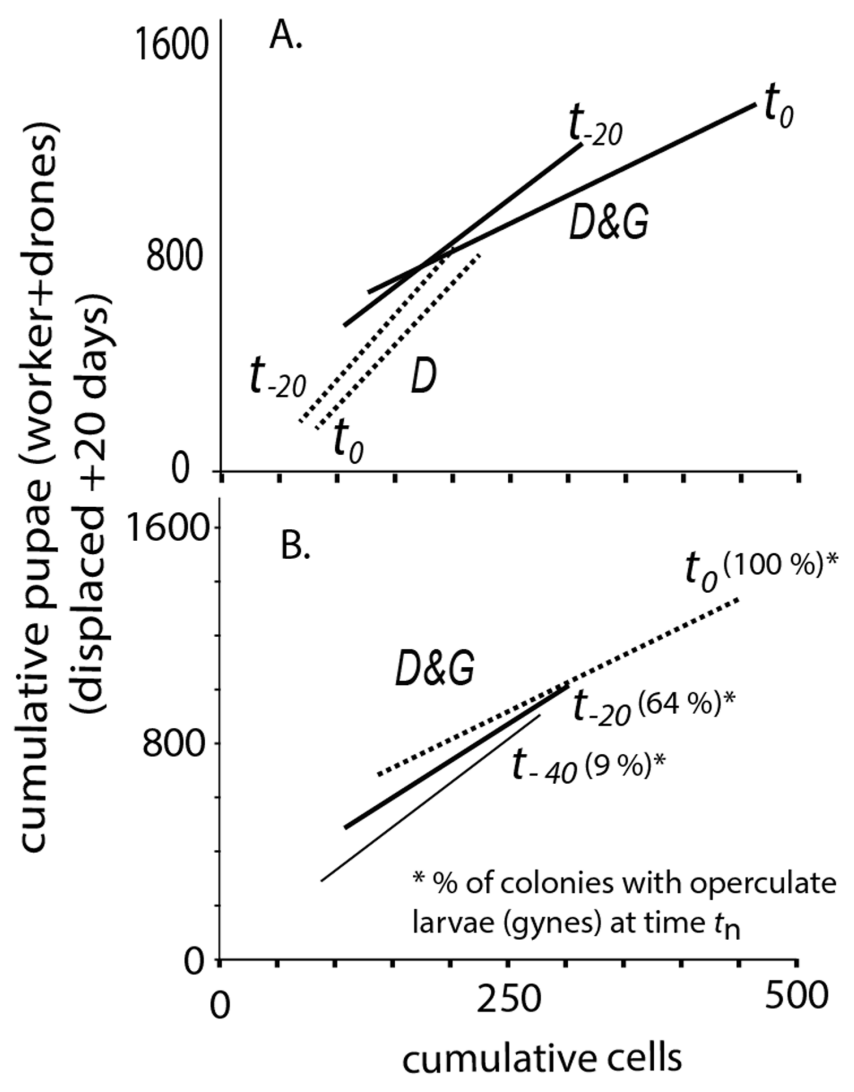

Fig. 8 Plots of cumulative pupae (workers + drones) (displaced +20 days), in 8 D\&G and 11 D colonies, on the cumulative number of cells, at different times during colony development relative to the time of the death of the queen (t0, t-20, t-40). A: Covariance analysis using class of colony (D\&G or D) as a treatment, and cells as a covariate at times t-20 and t0. B: Multiple regression analysis for D\&G colonies at times t0, t-20 and t-40 (see methods section).
A multiple regression analysis confirmed the progressive decrease in the slope of cumulative pupae on cumulative cells as D\&G colonies developed to the sexual phase (Fig. 8B). The slopes of the curves were consistently in the direction $\mathrm{t}_{-40}>\mathrm{t}_{-20}>\mathrm{t}_{0}$; specifically, at time $\mathrm{t}_{40} \mathrm{a}$ mean of 3.26 worker pupae/cell was produced, 2.66 pupae/cell at t ${ }_{20}$ and at 2.06 pupae/cell at $\mathrm{t}_{0}$. This confirmed the hypothesis that before the death of the queen, the colonies were preparing for the sexual phase of colony development. This was further borne out by the fact that at $\mathrm{t}_{-40}, 9 \%$ of the colonies had operculated gyne larvae, $64 \%$ at $\mathrm{t}_{-20}$ and $100 \%$ at $\mathrm{t}_{0}$.

The number of pupae per cell, the number of cumulative cells, and cumulative gynes and drones were depicted for three developmental outcomes of $D \& G$ colonies characterized below as types 1, 2 and 3 colonies (see Fig. 9).

Type 1 colonies - Four colonies $(n=4)$ produced sexual forms faster than the other colonies (type 1, Fig. $9 \mathrm{~A}-\mathrm{C}$ ). During the linear phase in these colonies, 3.7 cells were added per day (see isocline $a$ in Figure 9B). The number of pupae/ cell increased before stabilizing at a plateau of 3.5 pupae/cell for a period of about 34 days and then declined. The beginning of the plateau coincided roughly with the time when the first gyne-eggs were laid by the queen or about 40 days before first adult gyne emerged (see 


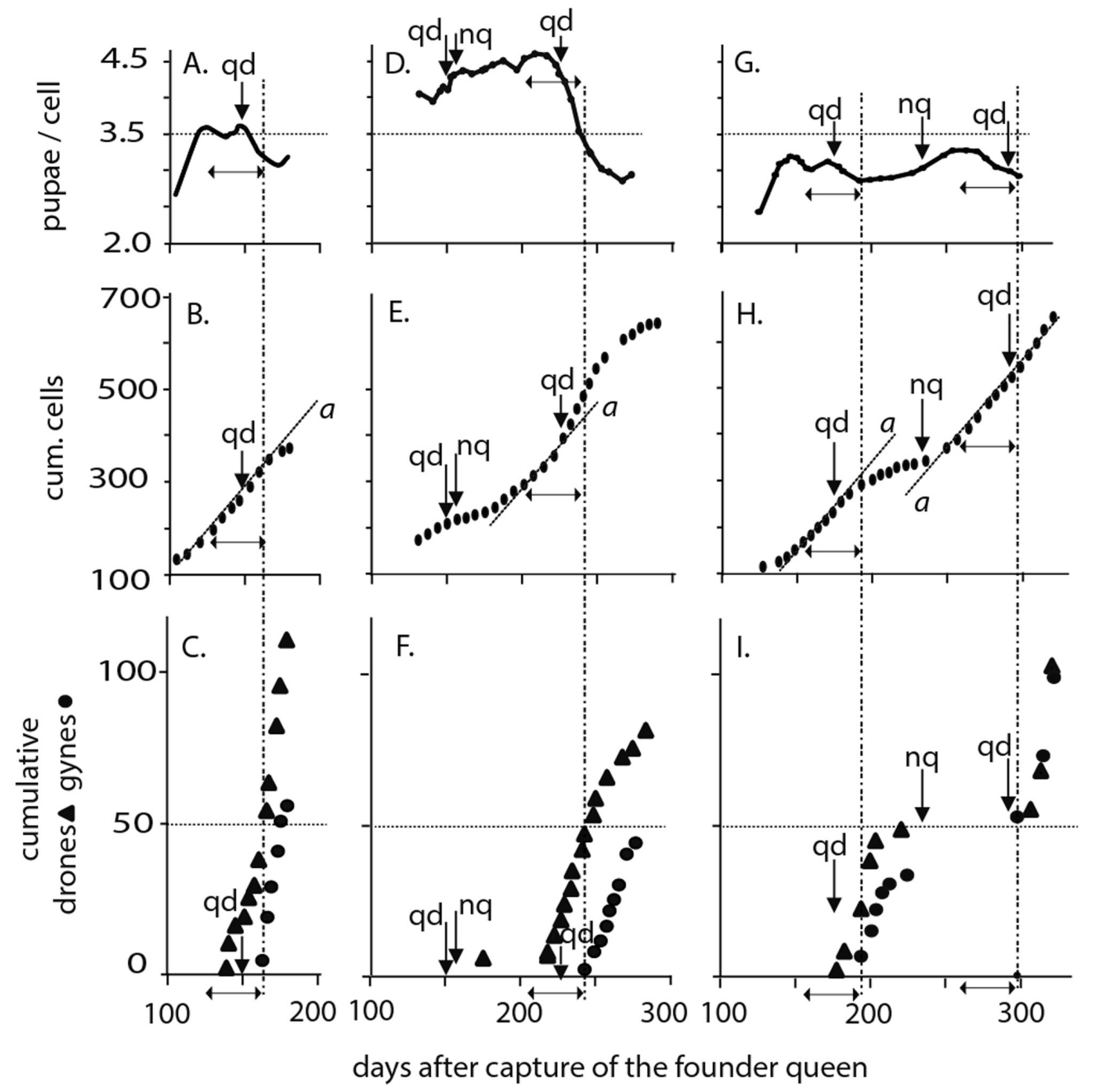

Fig. 9 Comparison between three types of colony development. Type 1 (A-C) Mean values of the colonies $(n=4)$ that produced sexual forms in the shorter period of time; Type $2(D-F)$ Colonies that lost the founder queen and were invaded by a new queen ( $n=2)$. Type 3 (G-I) Colony with two production cycles ( $n=1)$. A, D, G: Cumulative number of pupae (worker + drone) per cell. $\mathrm{B}, \mathrm{E}, \mathrm{H}$ : Cumulative number of cells with the isocline a with slope $=3.7$ was calculated from data in $B$, and used as a reference value for $E$ and $H$. C, F, I: Cumulative number of drones and gynes. In the figures, $\downarrow_{\text {qd }}=$ queen death, $\downarrow_{\mathrm{nq}}=$ new queen; the vertical dashed lines $=$ time the emergence of the first gyne; double arrow $(\leftrightarrow)$ indicates the estimated period from first gyne egg to first gyne adult (40 days).

the horizontal double arrow in Fig. 9) and the declined that occurred just after queen death at 147 DAC. The first adult drone appeared at 140 DAC, when the first gyne pupae were observed and the first adult gyne emerged on 161 DAC. An average of 121 drones and 60 gynes were produced in the $D \& G$ colonies (2:1 ratio). The average duration of the colony cycle from the initial capture of the queen to the production of the last gyne was 193 days. The values for type 1 colonies were used as references for comparisons to types 2 and 3 colony development.

Type 2 colonies - Two colonies $(n=2)$ were classed as type 2 and were characterized by very slow initial colony growth even though the longevity of the founder queens was 150 days and similar to the longevity of type 1 queens (Fig. 9 D-F). After the death of the queen, the type 2 colonies were reactivated by new queens from the outside that initiated a linear phase of colony growth that was steeper than in type 1 colonies (Fig. 9B vs. 9E). Compared to type 1 colonies, the first gyne produced by the new queens emerged earlier (85 days vs.161 days). By the time type 2 colonies were transferred to the field, they were bigger than type 1 colonies; consequently, the ratio pupae/cell was higher 
for type 2 than for type 1 (4.0 vs 2.5 pupae/cell) (Fig. 9A vs. 9D). The ratio of pupae/cell increased and plateaued at 4.4 for type 2 vs. 3.5 for type 1 (Fig. 9A vs. 9D). Gynes started to emerge 15 days after new queen death in type 2, which was the same as in type 1 colonies. Compared to type 1 colonies, type 2 colonies produced fewer drones (79) and gynes (43) but the ratio was the same $(\sim 2: 1)$. A few drones emerged after the death of the founder queen type 2 colonies.

Type 3 colonies - The third group of colonies $(n=3)$ successfully produced second or even third cycles of drones and gyne, but each cycle was produced by a new queen. All three colonies exhibited this behavior, but only one is illustrated in Fig. $9 \mathrm{G}-$-I. The number of cells per day during the linear phase was very similar in the two cycles, and were the same as in type

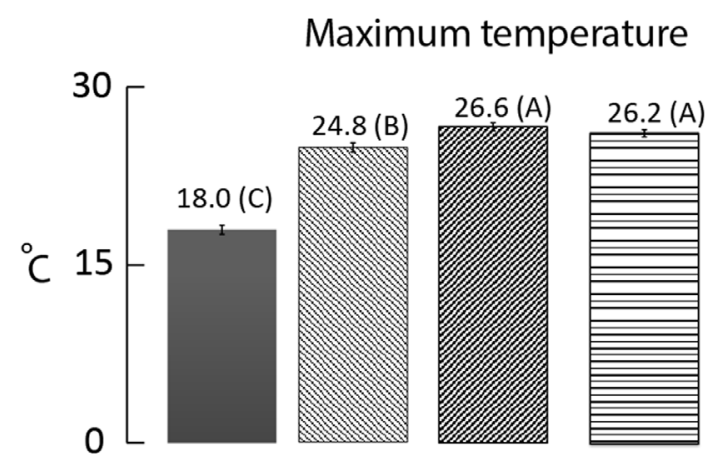

Average temperature
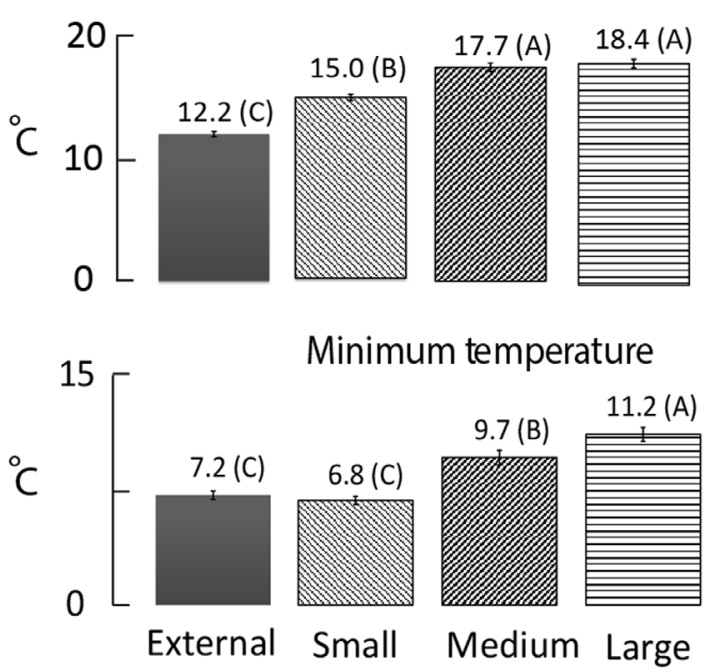

Fig. 10 Comparison between the internal and external temperatures of colonies with different number of workers when transferred to the field (see text). Bars with different letters show significant differences using Tukey's test).
1 colonies (Fig. 9B vs. 9H). The ratio of pupae to cells grew to a plateau of 3.0. The longevity of the founder queen was 179 days and the first gyne emerged 3 days later after its death. Compared to type 1 or type 2 colonies, fewer sexual forms were produced in the first cycle (47 drones and 32 gynes). Fourteen days after the emergence of all first-cycle gynes, a new queen took control of the colony and the ratio of pupae/cell increased to 3.3. In the second cycle, the time to first drones and gynes was reduced from 182 to 63 days, but the longevity of the new queen was only 57 days. The first gyne of the second cycle emerged six days after the death of the queen. 48 drones and 45 gynes were produced in the second cycle for a 1:1 ratio. The ratio drones to gynes over the two cycles was 1.23:1, which is lower than in single-cycle type 1 colonies. Using the number of sexual forms produced per queen as a metric of colony vigor, the colonies were classified as type 1 (vigor $=1)>$ type $2(=0.68)>$ type 3 second cycle $(=0.57)>$ type 3 first cycle $(=0.46)$.

\section{Temperature variation inside the colonies}

Internal temperatures were recorded for six differently sized colonies in the field and compared to ambient temperatures. The size of the colony was based on the number of workers present at the time the colonies were transferred to the field. The colonies were classified as small $(15 \pm 5$ workers), medium ( $45 \pm 10$ ) or large (170 \pm 10$)$. The maximum temperatures inside the colonies were higher than ambient for all colonies, with maximum and average temperatures being higher in large and medium size colonies than in small colonies $(P<0.05)$ (Fig. 10). Minimum temperatures were significantly higher than ambient in large and medium size colonies, but not in small colonies.

Hourly temperatures were compared to ambient temperatures throughout all phases of colony development in a medium size colony with 44 workers (Fig. 11). Mean internal temperatures in the colony were $20.8^{\circ} \mathrm{C}$ during the linear phase, $27.4^{\circ} \mathrm{C}$ during the sexual phase and $18.7^{\circ} \mathrm{C}$ during the post-sexual phase. These average internal temperatures were higher than ambient during 


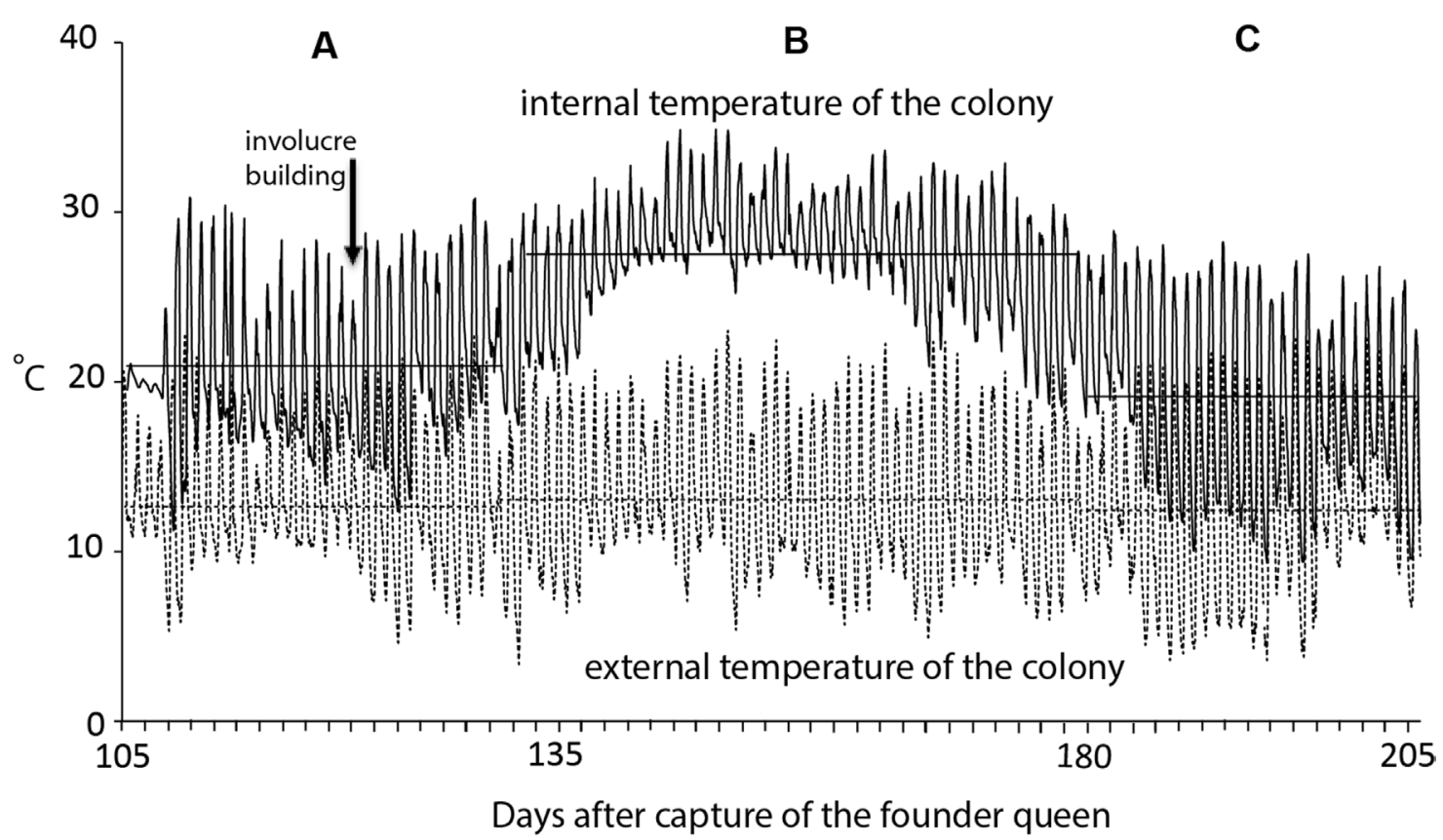

Fig. 11 Comparison between of hourly internal (upper line, ) and external temperatures (lower line, -----) during three phases of D\&G colony development with an initial 44 workers when transferred to the field. The horizontal lines are the average temperatures during the different periods of colony development: $(A)$ the linear phase of colony development, $(B)$ the sexual phase and $(C)$ the post-sexual phase. The time of involucre building is indicated by the down arrow.

all phases of colony development: $7.9^{\circ} \mathrm{C}$ higher during the linear phase (Fig. $11 \mathrm{~A}), 14.3^{\circ} \mathrm{C}$ during the sexual phase (Fig. 11B), and $6.1^{\circ} \mathrm{C}$ during the post-sexual phase after the emergence of the sexual forms (Fig. 11C). The construction of the waxy involucre by the workers during the linear phase starting at 122 DAC (vertical arrow in Fig. 11) served to decrease heat loss in the colony.

\section{DISCUSSION}

\section{Cell building and oviposition}

When the first workers emerged, the colony began to transition from the initiation phase to the linear phase of growth. The slope of the linear phase (i.e., cells/day) was a measure of queen vigor. Another measure was the number of worker adults reared from the cells. The average number of cells built per day by a queen of a $B$. atratus colony studied by Sakagami, Akahira \& Zucchi (1967) in Brazil was 2.1 \pm 0.3 with an average of $8 \pm 2$ eggs per cell, all of which survived to adults. In Colombia, González, Mejía \& Rasmussen (2004) observed that 1.5 cells were built per day, but $52 \%$ of the cells were destroyed by the workers, and the same rate was reported for $B$. terrestris by Duchateau \& Velthuis (1988). In our field colonies with the highest rates of cell production during the linear phase of growth (type 1 colonies), a mean of 3.7 cells was produced per day with the mean number of pupae/cell increasing from 2.5 to a plateau of 3.5. Some cell had as many as 8 pupae. The plateau of pupae/cell was reached 20 days after the linear increase in cell production began. We postulate that the transition to a near constant number of pupae per cell marks the initiation of the sexual phase of colony development, and reflects the higher investment costs of rearing immature gyne compared to rearing immature workers. The number of cells/ day and pupae/cell in type 1 colonies (see text) is a metric for the maximum growth potential of $B$. atratus colonies.

\section{Production of sexual forms}

In nature, maximizing the production of sexual forms, especially gynes, is the objective of $B$. atratus colonies. Prior studies by us have shown that captive fed $B$. atratus colonies unable to forage in the field rarely reach the sexual phase. Furthermore, our data shows that early transfer 
of colonies from the laboratory to the field increases the probability of $B$. atratus producing gynes, even though the colonies may have few workers at the time of transfer. On average, colonies developing into $D \& G$ colonies were transferred to open conditions 19 days earlier than colonies producing only drones. We hypothesize that essential nutritional factors are lacking in the diet of colonies reared in captivity. The behavior of handling and processing of pollen by the workers and presenting it to the immature siblings is disrupted, and the overabundance of food fails to stimulate initiation of sexual form production in the colony.

In contrast, workers that forage in the field choose what food to gather and they participate in all phases of larval rearing and feeding. Bumblebees are known to prefer high quality pollen with more total protein and higher essential amino acid content (Leonhardt \& Blüthgen, 2012). For example, red clover ( $T$. pratense) is a very important resource of nectar and produces high quality pollen for many species of bumblebees ( $B$. lucorum, B. hortorum, B. pascuorum, B. hortulanus, B. funebris), especially in urbanareas (Brian, 1951; Hanley et al., 2008; Hennig \& Ghazoul, 2011; Rubio, 2012). T. pratense was an important food resource for $B$. atratus in our study area with continuous flowering occurring throughout the year that peaked during December to February (Lobatón Cure \& Almanza, 2012). The maximum number of sexual forms in our study occurred in February in colonies transferred to the field the prior December (see Figure 3). We posit that success in producing gynes in these colonies was linked to the availability of an abundant supply of $T$. pratense inflorescences.

\section{Colony development}

In $B$. terrestris, some colonies exhibit an early switching to the production of sexual forms at the time the first male egg are produced by the queen. Some $B$. terrestris colonies have late switching and produce few or no drones, but some may produce many gynes (Duchateau \& Velthuis, 1988; Duchateau, Velthuis \& Boomsma, 2004). In B. perplexus, the first queens emerge
3.2 days after the first drones (Pomeroy \& Plowright, 1982), and in B. melaleucus, colonies start producing gynes earlier than drones (Hoffmann, Torres \& Neumann, 2004). Cnaani, Schmid-Hempel \& Schmidt (2002) studied 11 colonies of $B$. impatiens, of which three failed to reach the sexual phase, four produced drones and gynes, two colonies produced only gynes and two produced only drones. In $B$. impatiens, $9 \%$ of the workers in old colonies had mature oocytes and were able to lay eggs, but never did so in the presence of the queen or during the post-sexual phase (Cnaani, Schmid-Hempel \& Schmidt, 2002).

Zucchi (1973) observed in B. atratus colonies that $90 \%$ or more of all drones produced were developed from eggs laid by workers. In our studies, workers were not observed laying eggs in the presence of a viable queen but did so when the queen was weak or occasionally when the colony was in the post-sexual phase. In our study, all colonies that reached the sexual phase produced both drones and gynes, but no colonies produced only gynes.

In $B$. terrestris, colonies reared in chambers at $28^{\circ} \mathrm{C}$ and $60 \% \mathrm{RH}$ reached the linear phase 27 days after colony initiation, and 20 days later the queens laid the first drone egg (Duchateau $\&$ Velthuis, 1988). In $B$. atratus, the duration of the initiation phase was more variable. Limiting conditions such as temperature, resources shortfall and poor queen vigor could extend the initiation phase and decrease the number of cells produced per day during the linear phase of colony development. The linear phase in high vigor type 1 colonies started at 100 DAC, which was much earlier than in type 2 or type 3 colonies. In type 1 the first drone egg was laid 10 days after the initiation of the linear phase.

The emergence of drones occurred on average thirteen days after the queen death in $D \& G$ colonies and 26 days after the queen death for the $D$ colonies. We suggest that drones from $D \& G$ colonies were produced by the queen while those from the $D$ colonies were from eggs laid by the workers after the queen lost the control of the colony. In addition, in our studies, drones from $D \& G$ colonies were larger than drones from 
$D$ colonies. This has an implication on fitness as some studies suggest that larger drones have more sperm and transfer a higher quantity of sperm during copulation (Garófalo, Zucchi \& Muccillo, 1986; Baer, 2003). Our results differ from Silva-Matos \& Garófalo $(1995,2000)$ who found no differences in drone size between queen-led and queen-less $B$. atratus colonies.

Sexual production in bumblebees is strongly drone biased (Owen, Rodd \& Plowright 1980; Owen \& Plowright, 1982; Fisher 1987, 1992; Röseler \& van Honk, 1990; Beekman \& Van Stratum, 1998). In an analysis of eleven populations of seven Bombus species, Bourke (1997) calculated a male-biased ratio of 3:1. Using linear regression with a zero intercept throughout all $B$. atratus $D \& G$ colonies, we found that the number of gynes to total gynes plus drones gave a drone biased ratio of $2.27: 1$ (slope $=$ $0.44)$. Nevertheless, there is an ample variation among individual colonies, which show a comparatively high number of gynes (87 of 136 total gynes plus drones) to a low number of gynes (41 of 370 total gynes plus drones).

\section{Reactivation of colonies}

An important aspect of biology of $B$. atratus is its capacity to reactivate colonies and produce successive generations (Sakagami, Akahira, \& Zucchi, 1967; Zucchi, 1973; Silva-Matos \& Garófalo, 1995; Cameron \& Jost, 1998; Riaño et al. 2014). Colony reactivation occurs when a new queen takes control of the colony after the founder queen dies or loses vigor. The entrance of a new queen into a colony and coexistence with the old queen for short periods of time has been observed in $B$. atratus. Riaño et al. (2014) described a sequence of three invasions by new queens to the same nest as follows: the old queen was killed by the invading queen that then controlled the nest for a short period of time, but that in turn was replaced by a new invading second queen that successfully produced sexual forms. Silva-Matos \& Garófalo (1995) reported successive cycles in a colony controlled by sibling queens that occasionally remained in the nest and successfully defend territory. In four of our $B$. atratus colonies, two queens coexisted from 18-39 days, but only one developed the colony to the sexual phase. The coexistence of a young and old queen is not necessary for reactivation of a $B$. atratus colony, as a new queen can reactivate an orphan colony and successfully produce a generation of sexual forms.

In our studies, the mean duration of a complete cycle from the capture of the queen to the emergence of the last gyne was 193 days. This is equivalent to 2374 degree days above $10^{\circ} \mathrm{C}$ at a mean nest temperature of $22.3^{\circ} \mathrm{C}$. The mean time for completion of a cycle of a $B$. atratus in Brazil was $170 \pm 15$ days. When a new queen reactivates an orphan colony, the time required to produce sexual forms is half the time of the first cycle. In a perennial $B$. atratus colony studied by Zucchi (1973) in Ribeirão Preto, Brazil, two to three gyne production cycles per year were obtained with a mean of 128 gynes per cycle. The colonies had access to the open field and were able to produce three cycles because they were kept inside a chamber with temperature controls and bypassed the solitary phase of colony foundation during the second and third cycles. In our studies, a mean of 51 gynes was produced in the first cycle with a decline to 44 in the second cycle. The mean longevity of the founder queens in our studies was similar in both $D \& G$ and $D$ colonies (146 days, 1796 degree days), while in Brazil the mean longevity was $114 \pm 41$ days (Zucchi, 1973).

\section{Temperature inside colonies}

Bumblebees regulate the temperature of the nest for the developing brood (Heinrich, 2004) using the metabolic heat of the workers and the insulating effects of the wax involucre lining the rearing chamber. Regulating the nest temperature several degrees above the external temperature shortens the developmental time of the brood and is an important consideration in some areas where the time available for amassing resources prior to producing sexual forms may be short (Morse, 1982). We note that ventilation of the nest can also be used to decrease unfavorable high nest temperatures. Considerable energy savings are possible when 
the founding queen finds a place for the nest to take advantage of existing insulation that helps retain metabolically heat (Heinrich, 2004). $B$. atratus colonies with more than 50 workers were able to maintain an average temperature of $18^{\circ} \mathrm{C}\left(6^{\circ} \mathrm{C}\right.$ above the ambient temperature) and a minimal of $10.5^{\circ} \mathrm{C}\left(3.5^{\circ} \mathrm{C}\right.$ above the ambient temperature). However, smaller colonies with fewer workers were unable to fully regulate nest temperature during early colony development. By way of comparison with other Bombus species, nest temperatures for $B$. pascuorum were reported to vary between $24-33^{\circ} \mathrm{C}$ (Brian, 1952; Barrow \& Pickard, 1985) and $20-27^{\circ} \mathrm{C}$ for B. polaris (Richards, 1973).

The average internal temperature of the $B$. atratus colonies changed during the three phases of colony development (e.g., $20.8^{\circ} \mathrm{C}$, $27.4^{\circ} \mathrm{C}$ and $18.7^{\circ} \mathrm{C}$ respectively). Hasselrot (1960) and Wojtowski (1963) also reported differences in temperature in bumblebee nests during the different phases, where the initial and terminal phases had low fluctuating temperatures. In our study, the middle phase had constant temperatures independent of external meteorological conditions. This is the period when the largest numbers of workers are present and when drones and gynes are being produced. Temperatures during this middle period reported for $B$. agrorum, B. ruderarius, B. lapidarius and $B$. silvarum were $32^{\circ} \mathrm{C}$ and $33^{\circ} \mathrm{C}$ for $B$. terrestris (Hasselrot, 1960; Wojtowski, 1963).

\section{Concluding remarks}

An important bionomic characteristic of bumblebee species is that they are either pocket makers or pollen storers (Sladen, 1912; Sakagami, 1976). All commercially reared bumblebee species are pollen storers, as pocket makers have generally proven less suitable for domestication because they usually accept only the pollen that is put inside the pockets by the beekeeper, and this behavior is expensive and time consuming to accommodate (Velthuis \& Doorn, 2006). The best rearing results with pocket makers leading to the production of gynes were obtained when colonies were allowed to forage for their own food soon after the emergence of the first workers (Griffin et al., 1991). B. atratus is a pocket maker species, and in our studies early transfer of the colony to the field was an important factor in successful colony development leading to the production of gynes.

A colony is successful when it produces new gynes, but this depends heavily on the vigor of the founding queen, the quality and quantity of food available during colony development, nest placement and weather. A good combination of these factors minimizes the duration of the initiation and linear phases of colony growth and increases the production of the sexual forms. The vigor of the queen is a difficult variable to assess, but our results show that under field conditions, a vigorous colony can build a maximum of 3.7 cells per day and rear 3.5 adult workers per cell during the linear phase of colony growth. In our study, such colonies produced an average of 60 gynes and 121 drones per cycle. According to Michener (2007), the apparent uniformity of bumblebee morphological characters are monotonous when compared to the Euglossini and especially the Meliponini. However, bumblebees can exhibit great behavioral plasticity in colony development. For example, colonies that are delayed in building a worker population can be reactivated by a new queen and still be capable of producing gynes. The adaptive reactivation of colonies enables $B$. atratus colonies to achieve up to three cycles per year in the face of environmental and other hazards. Several colony survival strategies were observed in $B$. atratus colonies by Garófalo (1974) and Sakagami (1976): 1) Monogynic colonies with production of gynes that leave the nest and individually initiate a new colony; 2) Monogynic colonies with sibling queens ovipositing and defending territories in the same nest (polygyny) until just one queen remains; 3) Orphaned or weak colonies where large workers mate and defend territories until a new queen from outside takes control of the colony; 4) Colonies in post-sexual phase where large mated workers swarm and are joined by workers to form other nests to initiate a colony which survives until a queen enters and takes 


\section{APIC. SCL. VUL. f1 N1. 12017}

control. We observed only strategies 1) and 3) in our study.

The observed plasticity in B. atratus colony development and the limitations on the number of colonies that can be observed make it difficult to interpret and to compare the different growth patterns of the 31 colonies in our studies. Among the important factors influencing development of $B$. atratus colonies were the vigor of the founding queens, the influence of time in captivity before the colonies were put in the field, and the kinds and levels of resource available to them. Integrating the disparate observations and data on $B$. atratus in a dynamic manner requires the development of a model that captures the time varying rates of resource acquisition and allocation of each colony that includes the behavioral and physiological responses to variable weather and resource availability. A physiologically based demographic model (see Gutierrez, 1992) has been used to model the processes of resource acquisition and allocation in numerous plant and animal species, and similar applications are apparent for modeling $B$. atratus colony development.

Based on results obtained in this and other studies here discussed, the behavioral plasticity observed in Bombus atratus is a good starting point to explore new possibilities for rearing and optimizing the production of this species to be used in crop pollination.

\section{ACKNOWLEDGEMENTS}

This work was supported by a research fund from the Universidad Militar Nueva Granada Project CIAS-1569, 2014-2015, CASAS Global NGO, Kensington CA, USA, and the University of California, Berkeley, CA, USA.

\section{REFERENCES}

Abrahamovich, A., \& Díaz, N. (2002). Bumble bees of the Neotropical Region (Hymenoptera: Apidae). Biota Colombiana, 3(2), 199-214.

Aldana, J., Cure, J.R., Almanza, M.T., Vecil, D., \& Rodriguez, D. (2007). Efecto de Bombus atratus (Hyme- noptera: Apidae) sobre la productividad de tomate (Lycopersicon esculentum Mill.) bajo invernadero en la Sabana de Bogotá, Colombia. Agronomía Colombiana, 25(1), 62-72.

Almanza, M.T. (2007). Management of Bombus atratus bumblebees to pollinate Lulo (Solanum quitoense $L$ ), a native fruit from the Andes of Colombia. Doctoral Thesis. Germany: Cuvillier Verlag Gottingen.

Baer, B. (2003). Bumblebees as model organisms to study male sexual selection in social insects. Behavior Ecology Sociobiology, 54(1), 521-533. DOl: 10.1007/s00265-003-0673-5

Barrow, D., \& Pickard, R. (1985). Larval temperature in brood clumps of Bombus pascuorum (Scop.) Journal of Apicultural Research, 24(2), 69-75. D0l: 10.1080/00218839.1985.11100651

Beekman, M., \& Van Stratum, P. (1998). Bumblebee sex ratios: why do bumblebees produce so many males?, The royal society publishing - Proceedings of the Royal Society B, 265(1),1535-1543. DOl: 10.1098/rspb.1998.0469

Bourke, A. (1997). Sex ratios in Bumble bees. The royal society publishing - Philosophical Transactions of the Royal Society B: Biological Sciences, 352(1): 1921-1933. DOl: 10.1098/rstb.1997.0179

Brian, A.D. (1951). The pollen collected by Bumblebee. The Journal of animal ecology, 20(2), 191-194. DOl: $10.2307 / 1538$

Brian, A.D. (1952). Division of labor and foraging in Bombus agrorum Fabricius. The Journal of Animal Ecology, 27(1), 223-240. DOl: 10.2307/1959

Camelo, L., Diaz, L., Cure, J.R., \& Almanza, M.T. (2004). Morfología floral de la uchuva y comportamiento de visitas de la especie de abejorros Bombus atratus (Hymenoptera: Apidae) bajo invernadero. En resúmenes del XXXI Congreso de la Sociedad Colombiana de Entomología SOCOLEN (p.86). Bogotá - Colombia.

Cameron, S., \& Jost, M. (1998). Mediators of domi- 


\section{- PHDlllh Et Hl. - Gyne and drone production in Bombus atratus}

nance and reproductive success among queens in the cyclically polygynous Neotropical bumble bee Bombus atratus Franklin. Insectes Sociaux, 45(1), 135-149. DOl: 10.1007/s000400050075

Cnaani, J., Schmid-Hempel, R., \& Schmidt, J.O. (2002). Colony development, larval development and worker reproduction in Bombus impatiens Cresson. Insectes Sociaux. 49(1),164-170. D0l: 10.1007/s00040-0028297-8

Cruz, P., Almanza, M.T., \& Cure, J.R. (2007). Logros y perspectivas de la cría de abejorros del genero Bombus en Colombia. Revista Facultad de Ciencias Básicas, 3(1), 49-60.

Duchateau, M., \& Velthuis, H. (1988). Development and reproductive strategies in Bombus terrestris colonies. Behaviour, 1073), 186-207.

Duchateau, M., Velthuis, H., \& Boomsma, J. (2004). Sex ratio variation in the bumblebee Bombus terrestris. Behavioral Ecology, 15(1), 71-82. DOl: 10.1093/beheco/arg087

Everitt, B. (2005). An R and S-PLUS ${ }^{\circledR}$ Companion to Multivariate Analysis. London, UK: Springer.

Fisher, R.M. (1987). Queen-worker conflict and social parasitism in bumble bees (Hymenoptera: Apidae). Animal Behaviour, 35(1), 1026-1036. DOl: 10.1016/ S0003-3472(87)80159-8

Fisher, R.M. (1992). Sex ratios in bumble bee social parasites: support for queen-worker conflict theoгу? (Hymenoptera: Apidae). Sociobiology, 201), 205217.

Garófalo, C.A. (1974). Aspectos Evolutivos da Biologia da Reprodução em Abelhas (Hymenoptera, Apidae). Dissertação de Mestrado. Ribeirão Preto, Brasil: Universidade de São Paulo.

Garófalo, C.A., Zucchi, R., \& Muccillo, G. (1986). Reproductive studies of a neotropical bumblebee, Bombus atratus (Hymenoptera: Apidae). Revista Brasileira de Genetica, 9(2), 231-243.
González, V., Mejía, A., \& Rasmussen, C. (2004). Ecology and Nesting Behavior of Bombus atratus Franklin in Andean Highlands (Hymenoptera: Apidae). Journal of Hymenoptera Research, 13(2), 234-242.

Griffin R.P., Macfarlane R.P., Ende H J., \& Van Den. (1991). Rearing and domestication of long tongued bumble bees in New Zealand. Acta Horticulturae, 288(1), 149-153. DOl: 10.17660/ActaHortic.1991.288.19

Gutierrez, A.P. (1992). The physiological basis of ratio dependent theory. Ecology, 73(1), 1529-1553. DOl: $10.2307 / 1940008$

Gutierrez, A.P., Daxl R., Leon Quant, G., \& Falcon, L. (1981). Estimating economic thresholds for bollworm, Heliothis zea Boddie, and boll weevil, Anthonomus grandis Boh., damage in Nicaraguan cotton, Gossypium hirsutum L. Environmental Entomology,10(1), 872-879. DOl: 10.1093/ee/10.6.872

Hadfield, J. (2010). MCMC methods for multi-response generalized linear mixed models: the MCMCglmm R package. Journal of Statistical Software, $33(2), 1-22$.

Hanley, M., Franco, M., Pichon, S., Darvill, B., \& Goulson, D. (2008). Breeding system, pollinator choice and variation in pollen quality in British herbaceous plants. Functional Ecology, 22(1), 592-598. Dol: 10.1111/j.1365-2435.2008.01415.x

Hasselrot, T.B. (1960). Studies on Swedish bumblebees (genus Bombus Ltr.): Their domestication and biology. Opuscula Entomologia Supplementum, 171), 1-192.

Heinrich, B. (2004). Bumblebee Economics. Massachusetts, USA: Harvard University Press.

Hennig, E., \& Ghazoul, 」. (2011). Plant-pollinator interactions within the urban environment. Perspectives in plant ecology, evolution and systematic, 13(1), 137-150. DOl: 10.1016/j.ppees.2011.03.003

Hoffmann, R.E., Torres, A., \& Neumann, P. (2004). A scientific note on the nest and colony development 
of the Neotropical bumble bee Bombus (Robustobombus) melaleucus. Apidologie, 35(1), 449-450. DOl: 10.1051/apido:2004011

Leonhardt, S., \& Blüthgen, N. (2012). The same, but different: pollen foraging in honeybee and bumblebee colonies. Apidologie, 43(1), 449-464. DOl: 10.1007/s13592-011-0112-y

Liévano, A., Ospina, R., \& Nates, G. (1994). Contribución al crecimiento de la taxonomía del género Bombus en Colombia (Hymenoptera: Apidae). Trianea Acta Cientifica Tecnológica del INDERENA, 5(1), 221-233.

Lobatón, J.D., Cure, J.R., \& Almanza, M.T. (2012). Fenología y oferta floral de trébol rojo Trifolium pratense (Fabales: Fabaceae) en praderas de kikuyo Penissetum clandestinum (Poales: Poaceae), como fuente de alimento para Bombus atratus (Hymenoptera: Apoidea) en Cajicá, Colombia. Revista Facultad de Ciencias Básicas, 8(1), 18-27.

Maccullagh, P., \& Nelder, J.A. (1989). Generalized Linear Models. Second Edition. London: CRC press.

Michener, C.D. (1974). The social Behavior of the bees. Massachusetts: Harvard University Press.

Michener, C.D. (2007). The bees of the world. Second Edition. Maryland: The Johns Hopkins University Press.

Morse, D. (1982). Behavior and Ecology of Bumble bees. In Social Insects, Vol 3. (pp. 246-312). New York: Academic Press.

Onset Computer Corporation (2013) Indoor Use Data loggers. HOBO U12-012. Retrieved April 7, 2016, http://www.onsetcomp.com/products/dataloggers/412-012

Owen, R.E., \& Plowright, R.C. (1982). Worker-queen conflict and male parentage in bumble bees. Behavioral Ecology and Sociobiology, 77(1), 91-99. DOl: 10.1007/BF00300097

Owen, R.E., Rodd, F.H., \& Plowright, R.C. (1980). Sex ratios in bumble bee colonies: complications due to orphaning?. Behavioral Ecology and Sociobiology, 71), 287-291. DOl: 10.1007/BF00300669

Pacateque, J., Cruz, P., Aguilar, M.L., \& Cure, J.R. (2012). Efecto de la alimentación vía bolsillo en etapas tempranas de desarrollo de Bombus atratus (Hymenoptera, Apidae). Revista Colombiana de Entomología, 38(1), 343-346.

Pérez, M.M. (2014). Evaluación del abejorro Bombus atratus Franklin (Hymenoptera: Apidae) como polinizador en fresa (Fragaria x ananassa Duch. 'Camarosa') bajo invernadero. Tesis de Maestría en Ciencias Agrarias. Bogotá, Colombia: Universidad Nacional de Colombia.

Pomeroy, N., \& Plowright, R.C. (1982). The relation between worker numbers and the production of males and Queens in the bumble bee Bombus perplexus. Canadian Journal of Zoology, 6a1), 954-957. D0l: 10.1139/282-131

Riaño, D., Veloza, M., Cure, J.R., \& Almanza, M.T. (2014). Desarrollo de dos colonias de Bombus atratus (Hymenoptera: Apidae) mantenidas bajo dos modos de alimentación. Revista Facultad de Ciencias Básicas, 102), 132-141.

Riaño, D., Pacateque, J., Cure, J.R, \& Rodriguez, D. (2015). Pollination behavior and efficiency of Bombus atratus Franklin in sweet peppers (Capsicum annum L.) grown in a greenhouse. Revista Colombiana de Ciencias Hortícolas, 9(2), 259-267. DOl: http:// dx.doi.org/10.17584/rcch.2015v9i2.4182

Richards, K.W. (1973). Biology of Bombus polaris Curtis and B. hyperboreus Schonherr at Lake Hazen, Northwest Territories (Hymenoptera: Bombini). Quaestiones Entomologicae, 9(1), 115-157.

Romero, E., Pinilla, C., Cure, J.R., Riaño, D., Padilla, S., Aguilar, M.L. (2013). Desarrollo de un escenario de campo para el estudio de especies nativas de abejorros (Bombus spp.) de los Andes Colombianos (Hymenoptera: Apidae). Revista Facultad de Ciencias Básicas, 9(2), 200-211. 


\section{- PADlllh Et fll. _ Gyne and drone production in Bombus atratus,}

Röseler, P.F., \& Van Honk, C.G. (1990) Castes and reproduction in bumblebees. In Engels, W (Ed). Social insects: an evolutionary approach to castes and reproduction. (pp. 147-166). Berlin, Germany: Springer,;

Rubio, D. (2012). Disponibilidad, uso y preferencia por lo recursos florales en una comunidad de abejorros (Hymenoptera: Apidae: Bombus) en el páramo de Chingaza. Tesis de Maestría de la Facultad de Ciencias. Bogotá, Colombia: Universidad Nacional de Colombia.

Sakagami, S. (1976). Specific Differences in the Bionomic Characters of Bumblebees: A comparative Review. Journal of the Faculty of Science Hokkaido University Series VI. Zoology, 2033), 390-447.

Sakagami, S.F., Akahira, Y., \& Zucchi, R. (1967). Nest architecture and brood development in a neotropical bumblebee, Bombus atratus. Insectes Sociaux, 14(1), 389-413. DOl: 10.1007/BF02223686

Silva-Matos, E.V., \& Garófalo, C.A. (1995). Observations on the development of queenless colonies of Bombus atratus (Hymenoptera, Apidae). Journal of Apicultural Research, 34(1), 177-185. DOl: 10.1080/00218839.1995.11100903

Silva-Matos, E.V., \& Garófalo C.A. (2000). Worker life tables, survivorship, and longevity in colonies of Bombus (Fervidobombus) atratus (Hymenoptera: Apidae). Revista de Biología Tropical, 48(2/3), 657664.

Sladen, F.W. (1912). The humble bee, its life-history and how to domesticate it. London: Macmillan and Company.

Velthuis, H., \& Van Doorn, A. (2006). A century of advances in bumblebee domestication and the economic and environmental aspects of its commercialization for pollination. Apidologie, 371), 421-451. DOl: 10.1051/apido:2006019

Williams, P.H. (1998). An annotated checklist of bumble bees with an analysis of patterns of description (Hymenoptera: Apidae, Bombini). Bulletin of The Natural History Museum (Entomology), 671),
79-152.

Wojtowski, F. (1963). Studies on heat and water economy in bumblebee nests (Bombinae). Zoologica Poloniae., 13(1), 19-36.

Zucchi, R. (1973). Aspectos bionômicos de Exomalopsis aureopilosa e Bombus atratus incluindo considerações sobre a evolução do comportamento social (Hymenoptera, Apoidea). Tese de Doutoramento da Faculdade de Filosofia, Ciências e Letras de Ribeirão Preto. Ribeirão Preto, Brasil: Universidade de São Paulo.

Zuluaga, J. (2011). Evaluación de la actividad polinizadora de Bombus atratus (Hymenoptera: Apidae) en un cultivo de mora de castilla (Rubus glaucus). Tesis de Grado de la Facultad de Ciencias Básicas y Aplicadas. Bogotá, Colombia: Universidad Militar Nueva Granada. 